\title{
Identification of Problem Solving Pattern of Physics Based on Students Personality
}

\author{
Ragil Meita Alfathy ${ }^{1}$, Budi Astuti ${ }^{2}$, Suharto Linuwih \\ Departement of Physics Education, Postgraduate Program, Universitas Negeri Semarang \\ meita.alfathy@gmail.com ${ }^{1}$, b_astuti@gmail.com²
}

\section{Keywords:}

Problem Solving, Problem

Solving Pattern, Personality

Type

\begin{abstract}
Studies that reveal the patterns of problem solving have been widely practiced, but there is no studies have revealed a pattern of problem solving based on personality types especially in the field of physics. The aims of this study are to determine the patterns of physics problem solving based on student personality type. The method that used in this research is descriptive qualitative research with Investigation of Lived Experience type. Subjects in this study are 12th-grade science programs students of MAN 1 Banyumas that was determined by a stratified sampling approach. This sampling divides students into homogeneous groups based on Keirsey's four personality types, they are Guardian, Artisan, Rational and Idealist. Each personality type was chosen by nine students as the subject of the study which was determined using a purposive sampling technique. The results showed that the pattern of physics problem solving between Idealist, Artisan, Guardian, and Rational students consecutively are conceptual problem solving, intuitive-analogic problem solving, intuitive problem solving, and analogic problem solving.
\end{abstract}

\section{INTRODUCTION}

Problem solving is an important component in scientific disciplines including physics as they relate to phenomena or problems in everyday life (Gok, 2010; Ibrahim \& Rabello, 2012; Octor et al., 2015). According to Gagne in Mulyasa (2008), if a student is faced with a problem, students not only solve problems but also learn something new. Problem solving plays an important role in the learning process, which students can face problems more flexible (Mulyasa, 2008). According to the Partnership for 21st Century Skill Event in 2015, which reveals that problem-solving is one of the capabilities that students need to compete in their future.

The importance of problem solving in student life makes the basis why problem solving is central to Physics learning at any level. Because in problem solving activities, involve the process of analyzing, interpreting, reasoning, predicting, evaluating and reflecting (Anderson, 2009). Wood et al. (1997) further states that problem solving consists of defining problems, exploring problems, planning solutions, implementing solutions plans, checking solutions and evaluating (reflecting). Polya (1973) explicitly describes the problem solving pattern, which starts with understanding the problem, making plans, implementing the plan and re-examining the answers. Meanwhile Carin (1933), problem solving can be developed through the following patterns: (1) search, where students seek or select topics from personal experience, print or electronic media; (2) solve, students solve problems by applying information and research procedures qualitatively, quantitatively as well as correlative approach; (3) create, students collect and process information using images or graphs; (4) sharing, 
students communicate their findings with other students through the making of reports orally or in writing.

The problem solving pattern that approached the process of scientific inquiry proposed by Dewey (1933), the pattern are (1) understanding the problem, (2) proposing hypothesis, (3) executing the plan, (4) reviewing the answer and (5) drawing conclusions. This problem solving pattern is often used as an indicator of problem-solving in science learning, as it approaches a scientific-like process that similar to the core of the Curriculum 2013, which is based on scientific learning method. Based on that point, Dewey problem solving pattern is used as an indicator of problem solving in this research.

Juliyano et al. (2013), done a research that explains the difference in student problem-solving items influenced by the level of development of thinking. They also found some variation in student problem solving patterns at different ages, even in the same age there is also a tendency of difference although on a minor scale. That research indicates that the general theory of other domains can contribute to explain the variation in the pattern of problem solving of each student.

The relation between personality and problem solving pattern are: (1) basically problem solving pattern is thinking process from a series of rational mental ability (Abdullah \& Shariff, 2008; Dewiyani, 2008); (2) the thinking process starts from the receiving of information (from outside or from within the student), processing the information, storing and retrieving the information from student's memory (Surya, 2015). Keirsey (1998) in his book Please Understand Me formulated the similarity of characters from the theories of previous scholars, then managed to characterize the personality into four types, they named Guardian, Artisan, Rational and Idealist and also known as The Four Temperament Theory. Each personality type will certainly have its own character in expressing his ideas both orally and in writing.

Research to reveal problem-solving based on personality type has been done (Jackson, 2011; Pertiwi et al., 2014; Panjaitan, 2015; Zanberg et al., 2016), but still not many research has revealed problem solving pattern from any personality type view. Based on this fact, The Four Temperament Theory needs to be tested to identify the different of problem solving pattern as a result of differences in student personality types. Based on that description, the aim of this study is to analyze the physics problem solving pattern based on student personality type.

\section{RESEARCH METHOD}

The research method that used in this research is qualitative research method. The type of qualitative research that used in this study is Investigation of Lived Experience with Cognitive Psychology type (Gall et al., 2003). Research Investigation of Lived Experience is a qualitative research that explores inner experience about perception, memory, attention, thinking ability and problem-solving.

\section{Research Subject}

The data sources are the respondents who were determined by purposive sampling technique with a stratified sampling approach, which divides the students of 12th-grade science programs students of MAN 1 Banyumas into homogeneous groups. The grouping is based on four Keirsey (1998) personality types, they are Guardian, Artisan, Rational and Idealist types. Nine students represented each personality type was chosen by Purposive Sampling technique, based on considerations or opinions of teacher and researcher regard to criteria: (1) personality type, (2) students activity during physics learning and (3) completeness for students.

\section{Data Collection Technique}

The data that used in this study are entirely primary data were obtained directly from the subject. The methods that used in this research are (1) questionnaire method, which consists of 16 questions with 4 answer choices. The choice of answers is sorted by subject to classify them according to Keirsey (1998) personality type, they are Guardian, Artisan, Rational and Idealist; (2) written test, consist of problems regarding the analysis of the interaction of force and mass on the sloping plane and slippery 
plane and the identification of Newton's II law principles applicable in daily life. The multiple choice with reasons models are used to give students an idea how to answer questions quickly on a short time and avoid the answers to far from the topic problem; and (3) interview method, was done to the student after answering the written test. This method used to confirm and discover students' problem solving and the pattern of students' problem solving with giving questions that related to how students answer the questions and the students' reasons that used to answer questions in the written test before.

\section{Data Analysis Technique}

The data was analyzed by a fixed comparison method. Moleong (2002) explains the process of data analysis are: (1) processing, (2) reduction, (3) categorization and coding, and (4) make conclusions.

\section{Validity Technique}

Data in qualitative research must fulfill the requirements of transferability, dependability, and confirmability. Terms of transferability were obtained by describing the data in detail. Terms of dependability were obtained by taking 36 respondents with different personality types were divided into four personality types. Terms of confirmability were obtained by making interview guidelines, making a grid of test questions, and presenting the data according to the results in the field.

\section{RESULT AND DISCUSSION}

Based on the results of the description of respondents in solving the problem found the tendency of different patterns between the types of Guardian, Artisan, Rational and Idealist in solving physics problems.

\section{The Idealist Pattern of Physics Problem Solving}

Idealist students tend to have the ability to determine related concepts to solve the problems, which are then named as conceptual problem-solving patterns. I-5 can solve problem 3 about related to the application of Newton's law principle II in daily life about the phenomenon that makes the object seems to lose some of its mass. The reason that given by I-5 consist of the illustration of the picture that supported the explanation according to existing theory and equation. The result of I-5 answers to problem 3 further explored through the interview method. The result of an interview with I-5 on problem 3 that ask about phenomena that make things seem to lose some of their mass, shows in excerpts of an interview below.

$R:$ if on earth, there must be a gravity whose style leads to the center of gravity in the earth. I answered $D$, when in the elevator that moves down. When people in the elevator, its means the downward acceleration, then the gravity is going down towards the center of gravity in the earth. Then here, there is a mass of people, that's meaning there is a normal force upward that is positive then the weight is negative. Then the normal force minus weight minus acceleration equal to zero. Then the weight is equal to the normal force minus acceleration. If the elevator moves upward it means that the wight is actually equal to normal force added to the acceleration itself, so it will be even heavier.

$A$ : so what is the conclusion?

$R$ : when in a downward moving elevator it's the same way to lose some weight.

Based on the excerpt of the interview can be revealed in general, the pattern of Idealist problem solving starts with understanding the problem followed by choosing related concepts to solve the problem. Furthermore, some students designed sketches to facilitate the completion, whereas most did not perform such step. The next step is to propose a hypothesis which is a temporary answer. Some students review the selected answer by comparing the proposed hypothesis with another answer. The final step of the Idealist type problem-solving pattern is drawn conclusions to determine the final solution of the problem. To understand Idealist problem solving patterns, here given syntax that presented in Figure 1. 


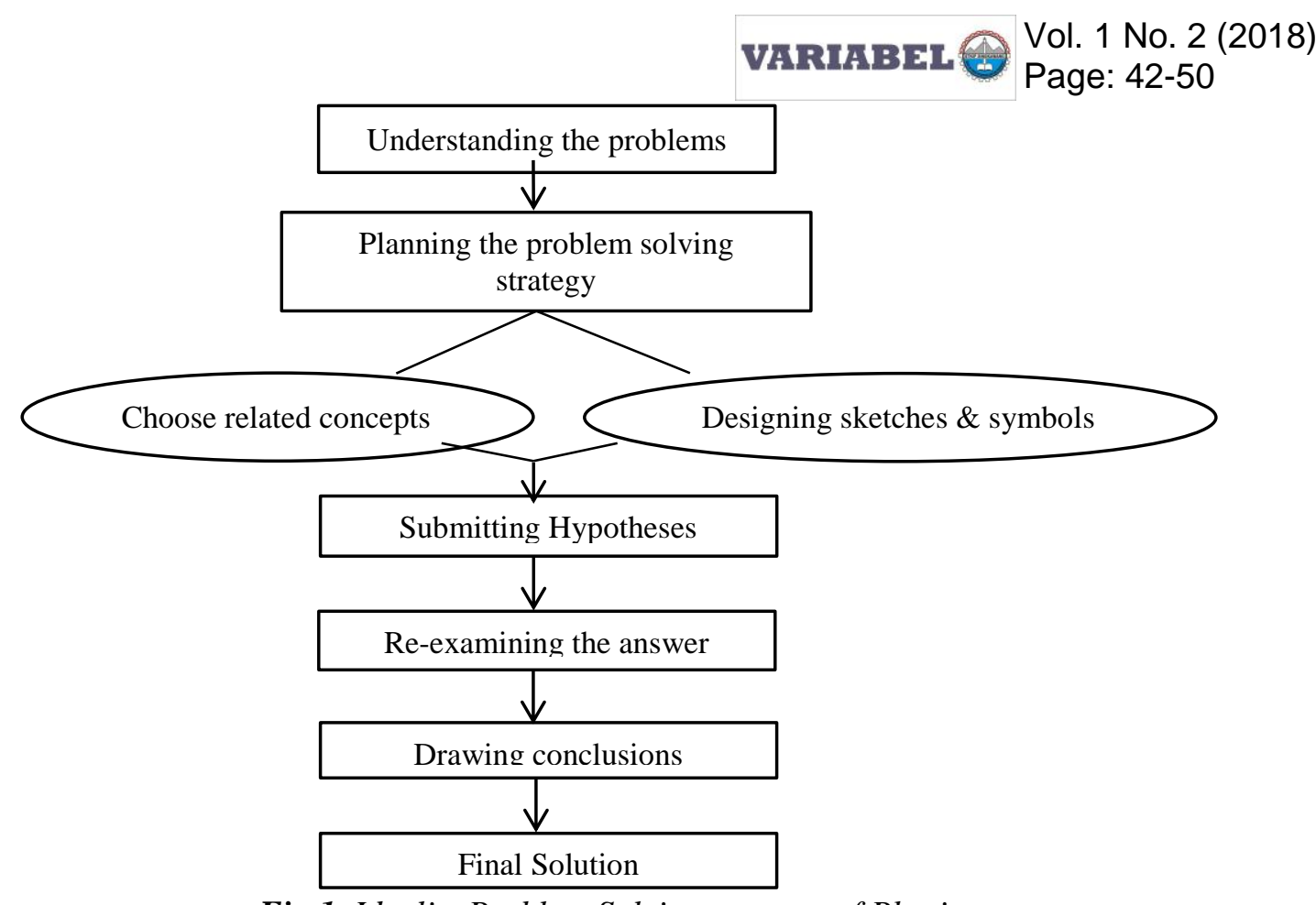

Fig 1. Idealist Problem Solving patterns of Physics

The results of the study of Idealist type indicate conformity with the theory of Kiersey (1998) who revealed the type of Idealist liked the material about ideas and values. Idealist types can look at issues from multiple perspectives. This is supported by the Idealist problem-solving capabilities that quite well comprehend the five indicators of Dewey's problems solving. This is evidenced by the results of the problem-solving test shown in Figure 2.

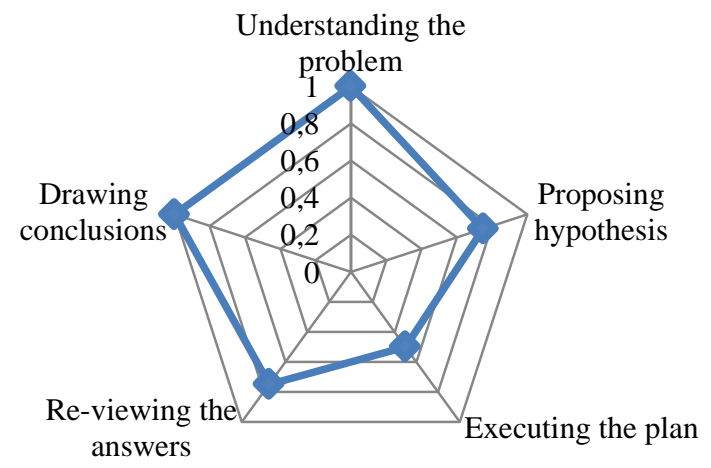

Fig 2. I-5Problem SolvingScore

From the above test results, can be seen that I-5 has the skills needed to solve the problem.

\section{The Artisan Pattern of Physics Problem Solving}

Artisan students have a different tendency to Idealist students. Artisan students have a tendency to complete a problem-solving plan using a combination of intuition and analogy, which further called an intuitive-analogic problem-solving pattern. Problem solving using intuition means that students do not do any planning in answering the problem. Students rely solely on intuition to choose an answer. Laksana et al. (2015) stated that Artisan type has a tendency for everything to be done quickly and even tend to be in a hurry. That means, solving the problem with intuition becomes a primary choice to solve the problem for Artisan students. This is shown in the result of written test A-6 on problem 3 related to the application of Newton's law principle II in daily life about the phenomenon that makes the object seems to lose some of its mass. The results then explored through interviews. The interview 


\section{VARIABEL Vol. 1 No. 2 (2018) \\ Page: $42-50$}

result shows A-6 has intuition thinking pattern and analogy in solving a physics problem. Here are excerpts of the interview with A-6 on problem 3.

$R:$ I think when jumping from a high-rise building.

$A$ : Why?

$R:$ Cause, there is no weight, it feels light. So there is no effect of gravity.

$A$ : Are you sure?

$R:$ for example, when we are in the elevator, we're still treading on the elevator, so we still felt the weight. Next option is, someone who swung himself too, he was up and down, the gravity still influences them that makes they back in the opposite direction after the push, of course, the weight is still same. So the answer that most appropriate that $E$, when jumping from high-rise buildings.

Based on the excerpt from the interview, it can be revealed in general the pattern of Artisan problem solving begins by understanding the problem and then forwarding the hypothesis which is a temporary answer. Some students review the selected answer by comparing the proposed hypothesis with another answer. The final step of the Artisan problem solving pattern is drawn conclusions to determine the final solution of the problem. Here given the syntax of Artisan problem-solving pattern that presented in Figure 3.

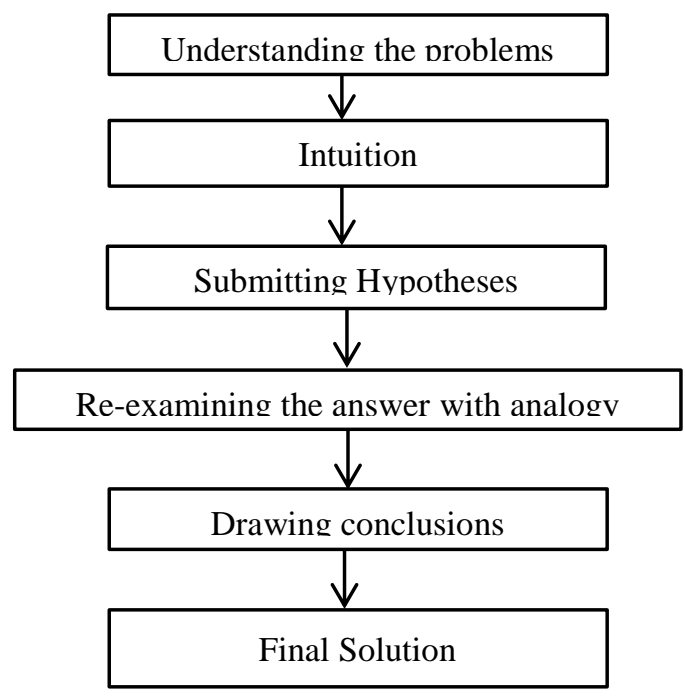

Fig 3. Artisan problem Solving patterns of Physics

Artisan students who have an intuitive-analogic problem-solving pattern, have a difficult tendency to express the exact concept in every physics problem solving. This made Artisan students choose to intuit to draw hypotheses and analogy strategies to reinforce the hypothesis. These discoveries are consistent with the results of the problem-solving test shown in Figure 4.

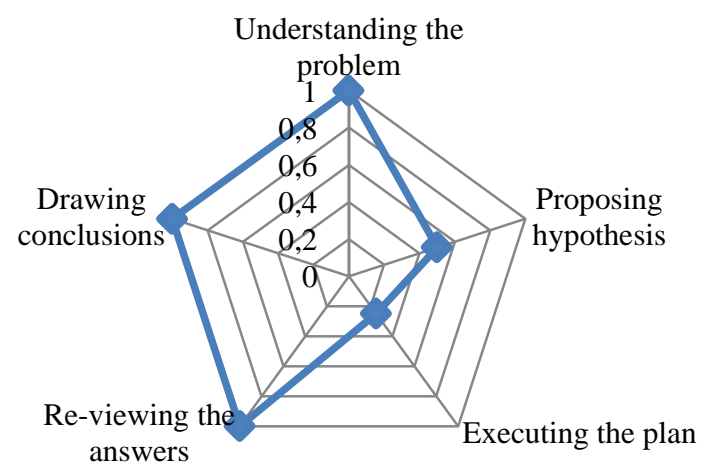

Fig 4. A-6 Problem Solving Score 
The low ability of Artisan students problem solving, allegedly as a result of Artisan type tendencies that want everything to be done and known quickly, often even tend to be too hasty (Kiersey, 1998).

\section{The Guardian Pattern of Physics Problem Solving}

Guardian students have similar tendencies to Artisan students. Guardian students have a tendency to complete a problem-solving plan using intuition. It is shown in the result of G-3 work on problem 7 relating to an object in the slippery field, the student is asked to find a solution to move the object with the lowest force value. The result of an interview with G-3 on problem 7 shows that G-3 has intuition thinking pattern in solving a physics problem, which then called intuitive problem solving pattern. The following is an excerpt of an interview with G-3 on Problem 7.

$R:$ because it is easier to pull than push

$A$ : why not push?

$R$ : because it's heavier

$A$ : how did you know its heavier?

$R$ : because squatting or sitting is heavier than standing

$A$ : so if pushing with a position like this, it is heavier than pulling?

$R$ : yes

$A:$ there is $60^{\circ}$ and $53^{\circ}$, why you choose $60^{\circ}$ ?

$R$ : because the angel is wide

$A$ : then?

$R:$ because of its like parallel to the foot

$A$ : parallel to the foot? What do you mean?

$R: 53^{\circ}$ was shortness so, maybe it will more easily with $60^{\circ}$

Based on the excerpt from the interview, it can be revealed in general the pattern of problem solving for Guardian students starts with understanding the problem. Once able to understand the problem, Guardian students tend to be able to directly propose hypotheses by using their intuition. Then, some students re-examine the chosen answer by comparing the proposed hypothesis with another answer using intuition. The final step of the Guardian problem solving pattern is to draw conclusions to determine the final solution of the problem. Here given the syntax of Guardian problem-solving pattern that presented in Figure 5.

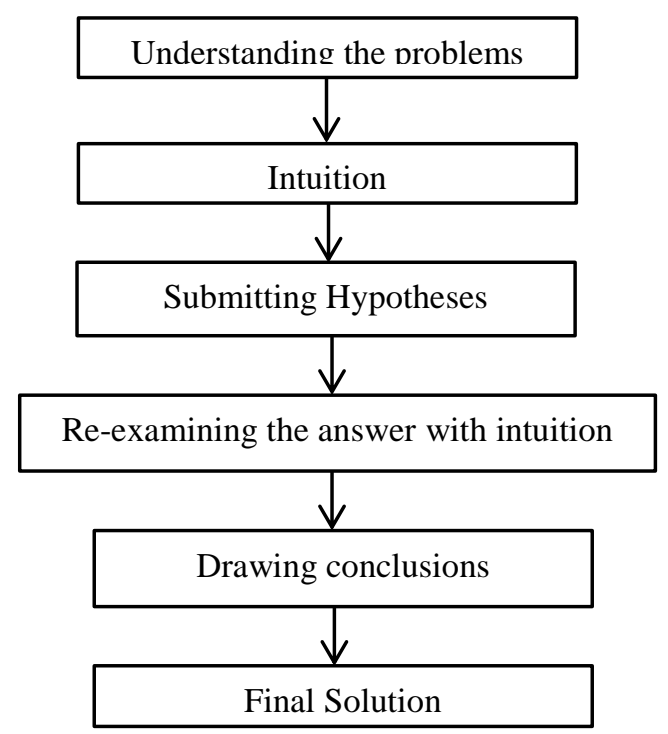

Fig 5. Guardian Problem Solving patterns of Physics

This discovery is consistent with the results of the problem-solving test shown in Figure 6. From the data, it can be seen that G-3 tends not to process the data so that in the process of determining the solution is directly taken from the result of the hypothesis or assumption. 


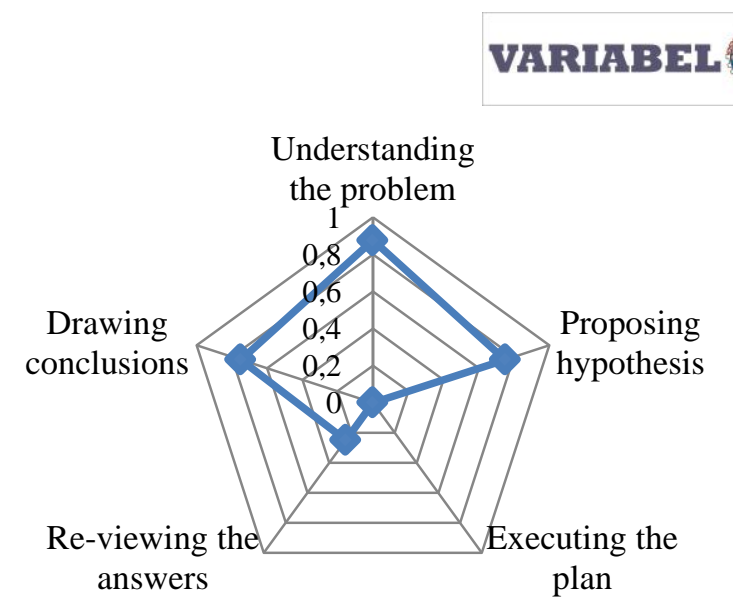

Vol. 1 No. 2 (2018)

Page: $42-50$

Fig 6. G-3 Problem Solving Score

Guardian students have intuitive problem-solving patterns that are almost identical to Artisan students. The difference is, the Guardian students take the hypothesis as the final solution after intuition. Some students re-examine on initial answers or hypotheses, but still use intuition with true and false boundaries. In this section lies the difference between the Guardian and Artisan students. While both equate to the hypothesis of intuition, the Artisan type tends to re-examine answers using an analogy.

\section{The Rational Pattern of Physics Problem Solving}

Rational students tend to analogize the problem with the phenomena that exist in daily life to make it easier to find the right solution. Although sometimes the analogy that they used does not contain the concept of physics, the Rational students are able to answer the problem quite well. This is shown in the excerpt of an interview with R-4 on problem 7 in the following paragraph.

$R:$ Because it feels easier to pull than push, for example when we move the table its more easily pull than push. Then the propulsion becomes less. Especially if on the slippery floor, easier to pull than push and more secure as well. If we push we can fall if the propulsion is too big..

$A$ : then why do you choose to pull with an angle of $60^{\circ}$ ?

$R$ : if $60^{\circ}$ so it means the direction is upward, so it's easier than $53^{\circ}$. If it is a little downward we will push it by bending (demonstrating). So it will make our movement tough.

The problem-solving pattern of Rational students begins by understanding the problem followed later by performing analogies and estimates method to solve the problem. Students use an analogy to solve existing problems by comparing it with the case of daily life that make the Rational student more easier to solve existing problems. The next step is to propose a hypothesis which is a temporary answer. Some students review the selected answer by comparing the proposed hypothesis with another answer. The final step is to draw conclusions to determine the final solution to the problem. To further understand the pattern, here given the syntax of Rational problem-solving pattern that presented in Figure 7.

Analogies that used in Rational students is influenced by his tendency to favor explanations based on Logic (Kiersey, 1998). This is evident from the results of the problem solving test shown in Figure 8. Rational type students are considered to have good enough ability for all indicators.

Based on the results of the research, there is a similar trend between Rational students and Artisan students. The basic difference is that Rational students have a tendency to take hypotheses and implement problem-solving plans using an approximate analogy. The result of an interview with R-4 on problem 7 shows that Rational type students have analogous thinking pattern in solving a physics problem, which then can be called a pattern of analogic problem solving. 


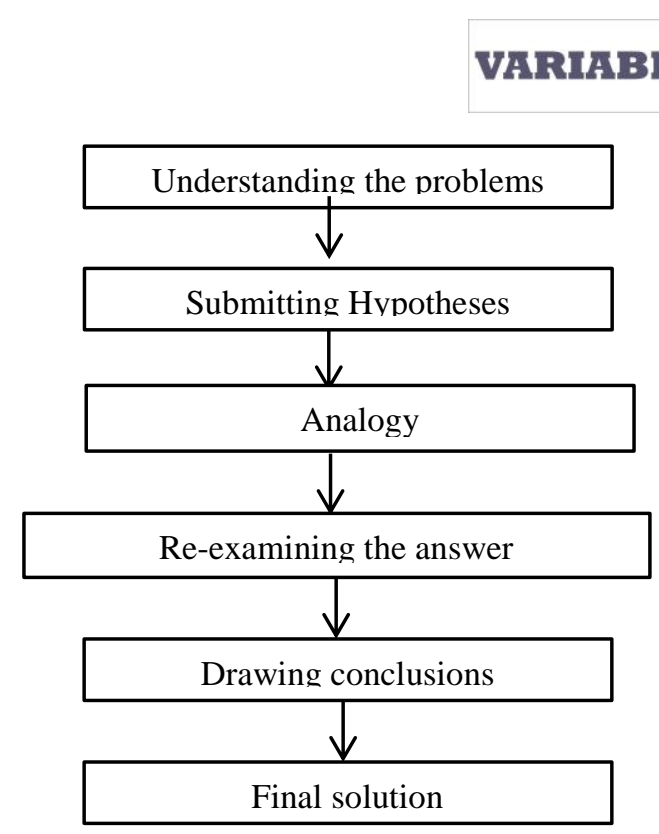

Fig 7. Rational Problem Solving patterns of Physics

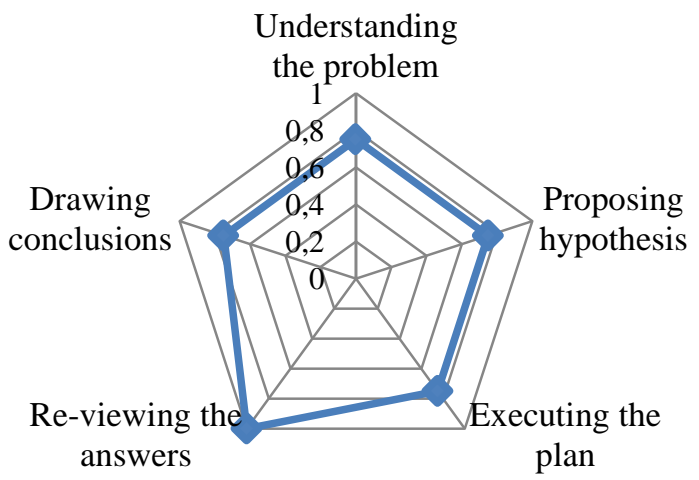

Fig. 8. R-4 Problem Solving Score

\section{CONCLUSION AND SUGGESTION}

A student's personality can affect his problem-solving pattern. Idealist students have a conceptual problem-solving pattern that makes it has good problem solving skills and is suitable for problem solving in the field of physics. Artisan students have intuitive-analogic problem-solving patterns that make it weak in the indicators of the ability to find appropriate problem-solving plans for physics concepts. Guardian-type students have intuitive problem-solving patterns, so this type has a low ability in implement problem-solving plans and re-examines answers. Students of the Rational type have problem-solving patterns of analogy, which analogize the problem with the phenomena present in everyday life. Therefore, the problem solving ability of Rational type students is considered good enough in all indicators. Based on these research, each of the different personality types reveals different patterns of problem solving. In addition, each personality type has its own weaknesses and advantages in solving problems, an analyze about solutions to overcome the weaknesses of students in solving problems according to personality is needed for advanced researchers.

\section{REFERENCES}

Abdullah, S. \& Shariff, A. (2008). The Effect of Inquiry-Based Computer Simulation with Cooperative Learning an Scientific Thinking and Conceptual Understanding of Gas Laws. Eurasia Journal of Mathematics, Science \& Technology Education, 4(4), 387-398. 
VARIABEL Vol. 1 No. 2 (2018)

Page: $42-50$

Anderson, J. (2009). Mathematics Curriculum Development and the Role of Problem Solving. Discussion Paper, ACSA National Conference on October 2009.

Carin, A. A. (1993). Teaching Modern Science. $6^{\text {th }}$ Edition. Columbus, Ohio: Merrill Publishing Company.

Dewey, J. (1933). How We Think. Boston: D. C. Health.

Dewiyani, S. M. J. (2008). Mengajarkan Pemecahan Masalah Matematika Berlandaskan Perbedaan Siswa. Proceeding, Seminar Nasional Matematika Institut Teknologi Sepuluh Surabaya, 13 Desember 2008.

Gall, M. D., Gall, J. P., \& Borg, W. R. (2003). Educational Research: an Introduction. $7^{\text {th }}$ Edition. New York: Pearson Education Inc.

Gok, T. (2012). The General Assesment of Problem Solving Processes and Metacognition in Physics Education. Eurasian Journal of Physics and Chemistry Education, 2(2), 110-122.

Ibrahim, B. \& Rabello, N. S. (2012). Representational Task Formats and Problem Solving Strategies in Kinematics and Work. Physical Review Special Topics-Physics Education Research, 8(1), $1-19$.

Jackson, J. J. (2011). The Effects of Educational Experiences on Personality Trait Development. Dissertation. Urbana, United State: Univerity of Illinois.

Keirsey, D. (1998). Please Understand Me II. United States: Prometheus Nemesis Books.

Moleong, L. J. (2002). Metodologi Penelitian Kualitatif. Edisi Revisi. Bandung: Remaja Rosdakarya.

Mulyasa, E. (2008). Menjadi Guru Profesional: Menciptakan Pembelajaran Kreatif dan Menyenangkan. Bandung: Remaja Rosdakarya.

Octor, J. L., Strand, N. E., Mestre, J. P. \& Ross, B. H. (2015). Conceptual Problem Solving in High School Physics. Physical Review Special Topics-Physics Education Research, 11(2), 1-13.

Panjaitan, B. (2015). Karakteristik Metakognisi Siswa dalam Memecahkan Masalah matematika Berdasarkan Tipe Kepribadian. Jurnal Ilmu Pendidikan, 21(1), 19-28.

Pertiwi, A. D., Masrukan \& Susilo. (2014). Analisis Kemampuan Komunikasi Matematis Melalui Pembelajaran Model 4K Berdasarkan Tipe Kepribadian Peserta Didik Kelas VII. Jurnal Kreano,5(2), 195-204.

Polya, G. (1973). How to Solve It. New Jersey: Princeton University Press.

Surya, M. (2015). Strategi Kognitif dalam Proses Pembelajaran. Bandung: Alfabeta.

Susanti, V. D. \& Swasti, M. (2016). Profil Berpikir Mahasiswa dalam Memecahkan Masalah Numerical Analysis Ditinjau dari Tipe Kepribadian. Jurnal Formatif, 6(1), 62-72.

Wood, D. R., Hrymak, A. N., Marshall, R. R., Wood, P. E., Crowe, C. M., Hoffman, T. W., Wright, J. D., Taylor, P. A., Woodhouse, K. A., \& Bouchard, C. G. K. (1997). Developing Problem Solving Skills: The McMaster Problem Solving Program. Journal of Engineering Education, 86(2), 75-91.

Zanberg, L., John L. Q., Marc N., \& Kees V. O. (2016). Personality-dependent Differences in Problem-solving Performance in a Social Context Reflect Foraging Strategies. Behavioural Processes J, 134(1), 95-102. 